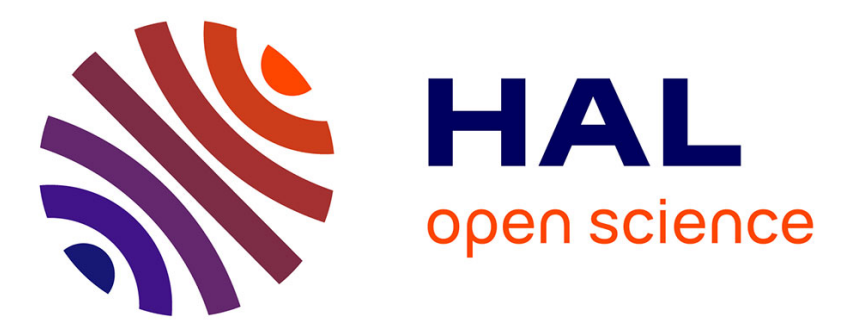

\title{
The Escherichia coli metallo-regulator RcnR represses rcnA and rcnR transcription through binding on a shared operator site: Insights into regulatory specificity towards nickel and cobalt
}

Didier Blaha, Safia Arous, Camille Bleriot, Corinne Dorel, Marie-Andrée

Mandrand-Berthelot, Agnès Rodrigue

\section{To cite this version:}

Didier Blaha, Safia Arous, Camille Bleriot, Corinne Dorel, Marie-Andrée Mandrand-Berthelot, et al.. The Escherichia coli metallo-regulator RcnR represses $\mathrm{rcnA}$ and $\mathrm{rcnR}$ transcription through binding on a shared operator site: Insights into regulatory specificity towards nickel and cobalt. Biochimie, 2011, 93 (3), pp.434 - 439. 10.1016/j.biochi.2010.10.016 . hal-01655156

\author{
HAL Id: hal-01655156 \\ https://hal.science/hal-01655156
}

Submitted on 27 Feb 2018

HAL is a multi-disciplinary open access archive for the deposit and dissemination of scientific research documents, whether they are published or not. The documents may come from teaching and research institutions in France or abroad, or from public or private research centers.
L'archive ouverte pluridisciplinaire HAL, est destinée au dépôt et à la diffusion de documents scientifiques de niveau recherche, publiés ou non, émanant des établissements d'enseignement et de recherche français ou étrangers, des laboratoires publics ou privés. 
Provided for non-commercial research and education use. Not for reproduction, distribution or commercial use.

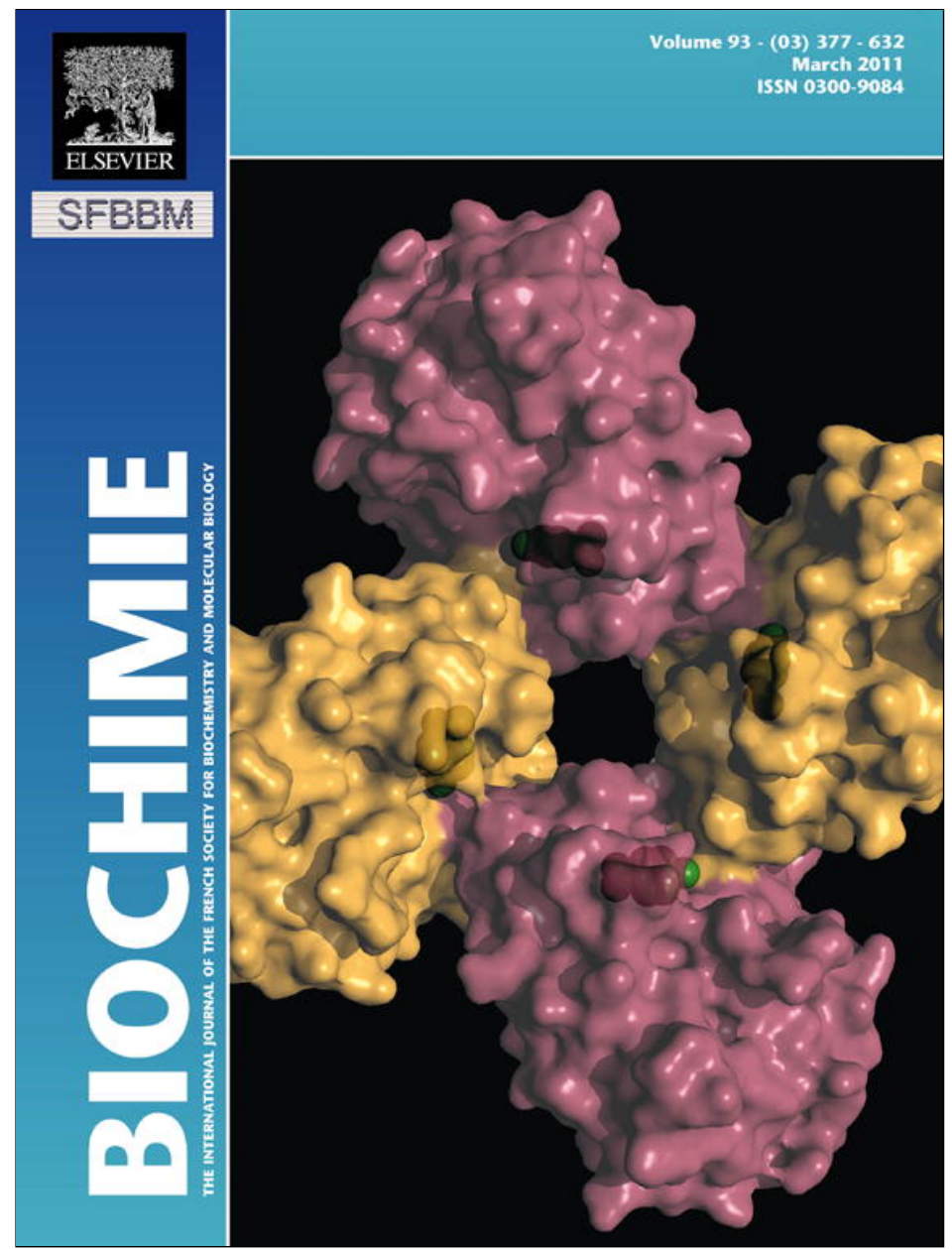

This article appeared in a journal published by Elsevier. The attached copy is furnished to the author for internal non-commercial research and education use, including for instruction at the authors institution and sharing with colleagues.

Other uses, including reproduction and distribution, or selling or licensing copies, or posting to personal, institutional or third party websites are prohibited.

In most cases authors are permitted to post their version of the article (e.g. in Word or Tex form) to their personal website or institutional repository. Authors requiring further information regarding Elsevier's archiving and manuscript policies are encouraged to visit:

http://www.elsevier.com/copyright 
Research paper

\title{
The Escherichia coli metallo-regulator RcnR represses $r c n A$ and $r c n R$ transcription through binding on a shared operator site: Insights into regulatory specificity towards nickel and cobalt
}

\author{
Didier Blaha ${ }^{1,2}$, Safia Arous ${ }^{1}$, Camille Blériot, Corinne Dorel, \\ Marie-Andrée Mandrand-Berthelot, Agnès Rodrigue* \\ Université de Lyon, Lyon France, UMR5240 Microbiologie Adaptation et Pathogénie, CNRS, INSA Lyon, Université Lyon 1, F-69622 Villeurbanne, France
}

\section{A R T I C L E I N F O}

\section{Article history:}

Received 18 September 2010

Accepted 20 October 2010

Available online 30 October 2010

\section{Keywords:}

Repressor proteins

Convergent promoters

Nickel

Cobalt

Homeostasis

\begin{abstract}
A B S T R A C T
RcnA is an efflux pump responsible for Ni and Co detoxification in Escherichia coli. The expression of $r c n A$ is induced by $\mathrm{Ni}$ and $\mathrm{Co}$ via the metallo-regulator RcnR. In the present work, the functioning of the promoter-operator region of $r c n R$ and $r c n A$ was investigated using primer extension and DNAse I footprinting experiments. We show that the promoters of $r c n R$ and $r c n A$ are convergent and that apoRcnR binds on symmetrically located sequences in this intergenic region. Moreover, RcnR DNA binding is specifically modulated by one $\mathrm{Ni}$ or Co equivalent and not by other metals. In addition to $\operatorname{rcnA}$, RcnR controls expression of its own gene in response to $\mathrm{Ni}$ and $\mathrm{Co}$, but the two genes are differentially expressed.
\end{abstract}

(c) 2010 Elsevier Masson SAS. All rights reserved.

\section{Introduction}

Nickel and, to a lesser extent, cobalt are obligate nutrients in bacteria because they fulfill important biological functions [1,2]. The intrinsic properties of these metals make them unique catalysts for a subset of specialized, vital functions. Biological systems have overcome the reactivity of these metals by evolving a large set of metal-coordinating proteins dedicated to metal transport and insertion [3]. Ni and Co are ubiquitous and are often co-localized in natural environments [4]. When present in excess concentrations, both metals are expelled out of the bacterial cell to ensure detoxification. In Escherichia coli, one $\mathrm{Ni}$ and Co export system, the RcnA efflux pump, has been reported. RcnA confers resistance to $\mathrm{Ni}$ and $\mathrm{Co}$, and its expression is induced by these two metals and not by other divalent cations [5]. The $r c n R$ gene, which is located upstream of the $r c n A$ gene and is divergently transcribed, encodes a repressor that controls rcnA expression in response to $\mathrm{Ni}$ and $\mathrm{Co}$ [6].

RcnR binds the intergenic $r c n R-r c n A$ region on the palindromic sequence TACT-G6-N-AGTA, which is repeated twice and interacts

\footnotetext{
* Corresponding author at: MAP UMR 5240, Bat Lwoff - 10 rue Dubois, F-69622 Villeurbanne Cedex, France. Tel.: +33 472447980; fax: +33 472431584.

E-mail address: agnes.rodrigue@insa-lyon.fr (A. Rodrigue).

1 Both authors contributed equally to this work.

2 Present address: Université de Lyon, Lyon, France, UMR5557 Ecologie Microbienne, Université Lyon 1, CNRS, and VetAgro Sup, ISPB, Lyon, France.
}

with flanking DNA regions, possibly resulting in DNA wrapping [7]. RcnR is thought to act as a tetramer, composed of a dimer of dimers [7] and to bind one Ni or Co ion per monomer, these metals being coordinated by a set of common residues as well as specific ligands [6]. RcnR is structurally similar to CsoR, a Cu-sensing repressor whose crystallographic structure reveals a homodimeric state in which $\mathrm{Cu}(\mathrm{I})$ is coordinated at the interface of the two monomers [8]. CsoR from Bacillus subtilis binds $\mathrm{Ni}(\mathrm{II}), \mathrm{Zn}(\mathrm{II})$ and $\mathrm{Co}(\mathrm{II})$ with high affinity in vitro. However, this binding does not affect the DNA binding affinity of CsoR, as these metals are coordinated at different positions relative to that of $\mathrm{Cu}(\mathrm{I})$ [9]. The metal specificity of the RcnR regulatory pathway was not clearly defined and the promoter elements of the $r c n R-r c n A$ intergenic region were not determined. The aim of the present work was therefore to gain insight into the regulatory features of the $r c n R$ and $r c n A$ genes via RcnR by using a combination of genetics and biochemistry.

\section{Materials and methods}

\subsection{Bacterial strains, plasmids and oligonucleotides}

The E. coli strains, plasmids and oligonucleotides used in this study are listed in Table 1 . Gene deletions of $r c n R$ and $r c n A$ were constructed in the E. coli BW25113 strain according to [10] using the primers listed in Table 1 . For phenotypical analysis, the $\operatorname{rcnR}$ deletion was transferred in E. coli NM522 by P1 phage transduction. 
Table 1

Bacterial strains, plasmids and primers used in this study.

\begin{tabular}{|c|c|c|}
\hline Strain or plasmids & Genotype or description & Source, reference \\
\hline \multicolumn{3}{|l|}{ Strains } \\
\hline BW25113 & lacl $^{\mathrm{a}} r r n B_{\mathrm{T} 14} \Delta \operatorname{lacZ}_{\mathrm{W} 16} h s d R 514 \Delta a r a B A D_{\mathrm{AH} 33} \Delta r h a B A D_{\mathrm{LD} 78}$ & {$[10]$} \\
\hline NM522 & $\Delta($ lac-proAB $)$, thi, hsdS, supE, [F' proAB+, lacI, lacZ $\Delta M 15]$ & Stratagene \\
\hline B834 & $F^{-}$ompT hsdS $S_{B}\left(\mathrm{r}_{\mathrm{B}}^{-} \mathrm{m}_{\mathrm{B}}^{-}\right)$gal $[\mathrm{dcm}]$ met $(\mathrm{DE} 3)$ & [20] \\
\hline DB150 & As NM522, $\Delta r c n R$-cat & This study \\
\hline ARY023 & As MC4100, rcnA::uidA-Kan ${ }^{\mathrm{R}}$ & [5] \\
\hline ARY024 & As NM522, rcnA::uidA-Kan ${ }^{\mathrm{R}}$ & P1 transduction from ARY023 \\
\hline \multicolumn{3}{|l|}{ Plasmids } \\
\hline pGEM-T Easy & Cloning vector, AmpR & Promega \\
\hline pET30 & Overexpression vector, $\mathrm{T} 7$ promoter, $\mathrm{Kan}^{\mathrm{R}}$ & Novagen \\
\hline pDB1 & rcnR cloned into pET30 & This study \\
\hline pDB2 & $r c n R A$ regulatory region cloned into pGEM-T Easy & This study \\
\hline pAR123 & yohL-yohN region in pUC18 & [5] \\
\hline p127 & rcnA::gfp in pPROBE & {$[21]$} \\
\hline Primers & Sequence $5^{\prime}-3^{\prime}$ & Purpose \\
\hline Youp & CGAGTCGTTTGCATCCGATGATGATAAATCG & Cloning of $r c n R$ \\
\hline Yolup & AGGTGTTCATATGTCTCATAC & Cloning of $r c n R$ \\
\hline Yompromdwn & GCTGAAGAAGAGTTGTAAATTCGG & PrcnRA probe \\
\hline yompromup & TCACTTCCCGCATCAGACC & PrcnRA probe \\
\hline yolFRTup1 & ATTTGATATATGAATCCAGCACCTTCAGAACGACATCCAGTGTGTAGGCTGGAGCTGCTTC & rcnR mutant \\
\hline yolFRTdwn1 & AAGAAAATGCTCGACGAGCCGCACGAATGCGCTGCAGTTTCATATGAATATCCTCCTTAG & rcnR mutant \\
\hline YoMATG & AATTCGGTCATGATAATAATTC & Primer ext. $r c n A$ \\
\hline Yol4 & CACGTTTTAGCTCATCCC & Primer ext. $r c n R$ \\
\hline Rpob1FQ & GAAGGGCAGTATGGTCTGGA & qRT-PCR rpoB \\
\hline Rpob1RQ & TCACCAGACGCAGTTTAACG & qRT-PCR $r p o B$ \\
\hline Rpoa $1 F Q$ & TGATGTCGAAATCGTCAAGC & qRT-PCR rpoA \\
\hline Rpoa $1 \mathrm{RQ}$ & TGTAGGCAATACGCTCCAC & qRT-PCR rpoA \\
\hline Yohm2FQ & GAAACGCCTGGTTCTTCATCC & qRT-PCR $r c n A$ \\
\hline Yohm2RQ & AGGCAATTAACCAGACCACTG & qRT-PCR $r c n A$ \\
\hline yohl1FQ & TCGGCAATCTGATTCTACTCC & qRT-PCR $r c n R$ \\
\hline yohl1RQ & CTGGCCCTGAATCTTACTGG & qRT-PCR $r c n R$ \\
\hline
\end{tabular}

\subsection{Overexpression and purification of the RcnR Protein}

The coding region of $r c n R$ was cloned into pET30 using primers Youp and Yolup to generate pDB1 (Table 1). Overproduction of the native RcnR was carried out in E. coli B834 strain. Cells were grown at $29^{\circ} \mathrm{C}$ in LB medium containing ampicillin until OD $600 \mathrm{~nm}$ reached 0.6, $1 \mathrm{mM}$ IPTG was added and cells were grown for an additional $6 \mathrm{~h}$ at $29^{\circ} \mathrm{C}$. Cells were collected by centrifugation, washed and resuspended in $10 \mathrm{mM}$ sodium phosphate $\mathrm{pH} 7$ (binding buffer). Crude protein extracts were obtained by disrupting the bacterial cells with a French pressure cell (Aminco) and the lysed cells were centrifuged at $20000 \times g$ for 30 min to obtain clear lysates. The protein solution was first applied to a $5 \mathrm{ml}$ HiTrap heparin column HP (GE Healthcare), the loaded column was washed with the binding buffer and bound proteins were eluted using a $\mathrm{NaCl}$ linear gradient $(0.1-2.5 \mathrm{M})$. RcnR eluted in the $0.3 \mathrm{M}$ $\mathrm{NaCl}$ fraction. The RcnR fraction dialysed against $50 \mathrm{mM}$ sodium phosphate $\mathrm{pH} 6.5$ was loaded onto $1 \mathrm{ml}$ HiTrap cation exchange column (GE Healthcare). The bound proteins were eluted with $\mathrm{NaCl}$ linear gradient $(0.1-1 \mathrm{M})$ in $50 \mathrm{mM}$ sodium phosphate $\mathrm{pH} 6.5$. The RcnR protein was efficiently eluted with $0.2 \mathrm{M}$ of $\mathrm{NaCl}$, this fraction was buffer-exchanged on NAP-10 column (Amersham Biosciences) into complexation buffer (24 mM Hepes, $8 \mathrm{mM}$ Tris- $\mathrm{HCl}, 140 \mathrm{mM}$ $\mathrm{KCl}, 10 \%$ glycerol, $\mathrm{pH}$ 7.4).The protein concentration was determined by the method of Bradford (BioRad kit) and by measurement of OD at $280 \mathrm{~nm}\left(\varepsilon=1490 \mathrm{M}^{-1} \mathrm{~cm}^{-1}\right)$.

\subsection{In vitro $D N A-$ protein interaction}

The E. coli $r c n R-r c n A$ regulatory region ( $\operatorname{RrcnA})$ was amplified by PCR using the yompromdwn and yompromup primers. The resulting 325-bp amplification product was cloned into the pGEM-T Easy Vector (Promega). The RRrcnA DNA fragment obtained by a restriction digest with SalI and SacII was end labeled by filling the SacIl end in the presence of $\left(\alpha_{-}{ }^{32} \mathrm{P}\right)$ dCTP and DNA polymerase. DNAse I footprinting was performed using a modified version of a procedure previously described [11]. About $50000 \mathrm{cpm}$ of DNA probe was incubated for $15 \mathrm{~min}$ at $30^{\circ} \mathrm{C}$ with $10-200 \mathrm{nM}$ of RenR into complexation buffer. The reaction mixtures were adjusted to $10 \mathrm{mM} \mathrm{MgCl}, 5 \mathrm{mM} \mathrm{CaCl} 2$ and $0.1 \%$ (v/v) Nonidet P-40 (Roche Applied Science), supplemented with metals at the concentrations indicated in the figures and incubated for $15 \mathrm{~min}$ at $30^{\circ} \mathrm{C}$. DNAse I was added $\left(5 \times 10^{-3}\right.$ units; Roche) and incubated at $30^{\circ} \mathrm{C}$ for $15 \mathrm{~s}$. The digestion was blocked by the addition of $25 \mu \mathrm{l}$ of stop solution ( $100 \mathrm{mM}$ EDTA, $\mathrm{pH} 8$ ), and $50 \mu \mathrm{l}$ of ice-cold TE ( $50 \mathrm{mM}$ Tris- $\mathrm{HCl}$, $1 \mathrm{mM}$ EDTA, pH 7.5) was then added to increase the volume of the mixture. After phenol-chloroform extraction, DNA fragments were ethanol precipitated, resuspended in $10 \mu \mathrm{l}$ of formamide-dye mixture and separated by electrophoresis on a $6 \%$ polyacrylamide sequencing gel. Bands were detected by autoradiography.

\subsection{Primer extension}

Total RNA was extracted from E. coli NM522 cells by the TRIzol reagent method (Invitrogen). Total RNA was treated by DNase (Ambion), and $5 \mu \mathrm{g}$ RNA was annealed with approximately $6 \times 10^{4} \mathrm{cpm}$ of a ${ }^{32}$ P-end-labeled $19-20$-mer oligonucleotide (YoMATG for $r c n A$ and YoL4 for $r c n R$ ) in annealing buffer (Invitrogen). Extension reactions were performed with $1 \mu \mathrm{l}$ of SuperscriptII RT (Invitrogen), and products were fractionated on sequencing gels. Dideoxy sequencing reactions performed with the 
same oligonucleotide and the plasmid pAR123 were used as size markers.

\section{5. cDNA synthesis and real-time $P C R$}

Total RNA was extracted using the RNeasy kit (Qiagen). RNA was treated with DNase (Ambion). cDNA synthesis was performed with the SuperscriptII kit (Invitrogen). The real-time PCR experiments were performed using the Master ${ }^{\text {PLUS }}$ SYBRGreen I kit (Roche Applied Science). The $r p o B$ and $r p o A$ genes were chosen as reference genes for data normalization. Amplification and detection of the specific products were carried out with the LightCycler System, and data analysis was performed with the Lightcycler Relative Quantification software (Roche Applied Science). Relative expression was calculated as the ratio of the normalized value of each sample relative to that of the corresponding untreated wild-type cells according to [12].

\section{Results}

3.1. Transcription of renA and rcnR: convergent promoters for a shared operator

The E. coli $r c n A$ and $r c n R$ genes are divergently orientated. Their translation start codons are separated by $120 \mathrm{bp}$. The transcription start site for each gene was mapped by primer extension experiments. A single primer extension product was detected for $r \mathrm{CnA}$ or $\operatorname{rcnR}$ (Fig. 1A, B). The $r c n A$ start site is located $90 \mathrm{bp}$ upstream of the ATG, and the rcnR start site is located $107 \mathrm{bp}$ upstream from the ATG. The two transcript starts are thus separated by $75 \mathrm{bp}$. A striking feature of these genes is that the two promoters are

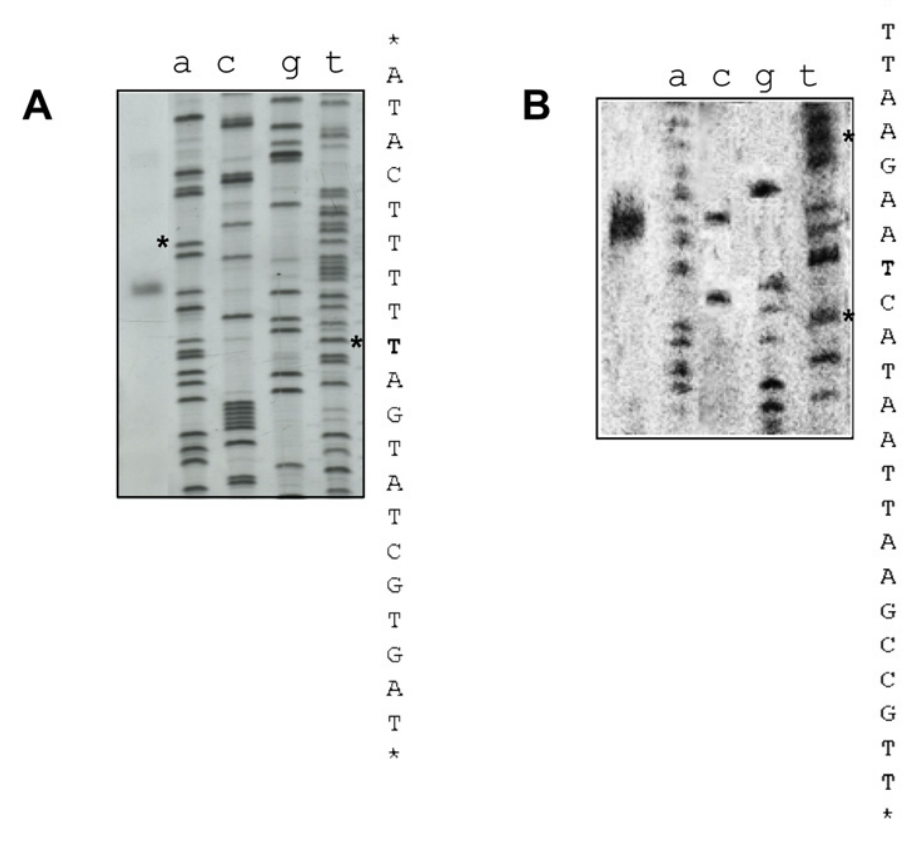

\section{C}

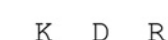

RCnR

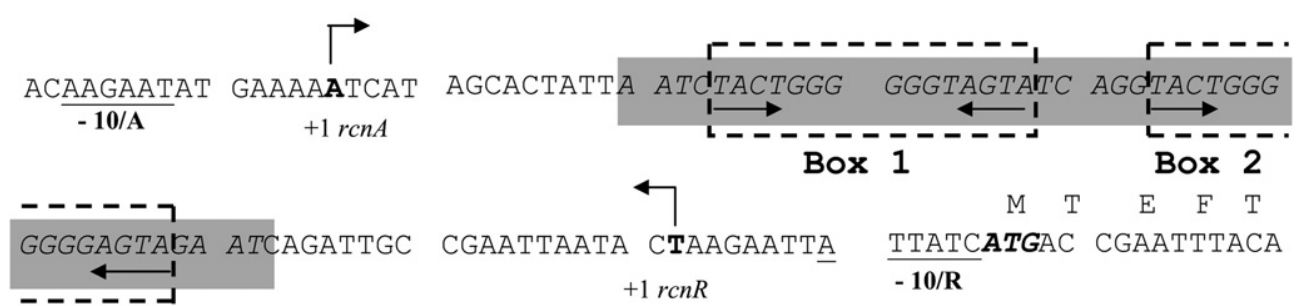

T L L $Q$ Q $\quad$ G N

RenA

$$
-35 / R
$$

Fig. 1. Intergenic region organization of $r c n A$ and $r c n R$. Determination of transcription initiation start sites of (A) $r c n A$ and (B) $r c n R$ using primer extension experiments. The DNA sequence surrounding the initiation site is written on the right, the +1 is in bold letter. (C) Sequence and organization of the region. The transcription start sites are indicated by bent arrows. The deduced -10 and -35 sequences are underlined (/A refers to $r c n A$ and/R refers to $r c n R$ ). The protected region in the footprinting experiments is shaded gray (see Fig. 2A). Inverted repeated sequences are underlined with arrows. The two repeated RcnR binding boxes are framed with dashed lines. 
convergent, an unusual topology among divergently transcribed genes.

The sequence surrounding the two start sites contains a palindromic sequence, TACT-N7-AGTA recognized by RcnR [7], which is repeated twice, with the two directly repeated dyad symmetry sequences separated by $5 \mathrm{bp}$. These two repeated sequences are located in between the $r c n A$ and $r c n R+1$, downstream of each site (Fig. 1C). DNAse I footprints in the presence of purified RcnR confirmed the occupancy of a 43-bp region covering the two boxes (Fig. 2A) using here a 325-bp probe located from -166 to +159 bp relative to the ATG of $r c n R$ [7]. Our determination of the transcription start sites highlights the symmetrical organization of RcnR binding sites towards the $r c n A$ and $r c n R$ promoters. The fact that RcnR binds downstream of both transcription start sites suggests that repression of transcription hampers RNA polymerase progression in both directions.

\subsection{Transcriptional control of renA and renR genes by Ni and Co via $r c n R$}

DNase I experiments were further carried out in the presence of $\mathrm{Ni}$ or Co (Fig. 2A). As expected, RcnR dissociates from its cognate binding site upon the addition of one or the other metal. This dissociation has been previously shown but using EMSA experiments and in the presence of a large excess of Ni or Co ([metal]/ [protein] $>10^{3}$ ) [13]. In the present work, after the addition of one metal equivalent of either metal, a release of $80-100 \%$ of RcnR from

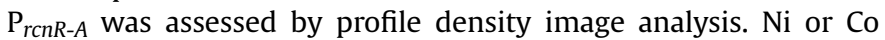
binding by RcnR was monitored using UV-visible spectroscopy.
The primary band for Co binding was at $308 \mathrm{~nm}$, and the primary band for Ni binding was at $278 \mathrm{~nm}$. We observed a stoichiometry of one $\mathrm{Ni}(\mathrm{II})$ or $\mathrm{Co}(\mathrm{II})$ binding to each RenR monomer (data not shown), in agreement with data published elsewhere [6]. Overall, these results show that RcnR responds similarly to $\mathrm{Ni}$ and $\mathrm{Co}$ in vitro.

The respective expression of $r c n A$ and $r c n R$ in the presence of either metal was assessed at the mRNA level by quantitative realtime PCR (Fig. 3). Cells were grown in LB medium in the presence of either Ni or Co from the start of the culture until mid-log phase. The chosen concentrations of $\mathrm{Ni}$ and $\mathrm{Co}(1 \mathrm{mM} \mathrm{NiSO} 4$ and $0.1 \mathrm{mM}$ $\mathrm{CoCl}_{2}$ ) gave the highest responses with the $\operatorname{rcn} A::$ uidA gene reporter fusion ([5] and data not shown). This difference between effective concentrations of $\mathrm{Ni}$ and $\mathrm{Co}$ has been reported elsewhere [14] and may be explained in terms of actual free metal concentrations in the cytoplasm. As expected, the expression of $r c n A$ in a wild-type background was induced by either Ni or Co (Fig. 3). The induction by these two metals was nearly the same, approximately tenfold. In the $\Delta r c n R$ derivative, similar expression ratios were obtained for $r c n A$ in the three tested conditions, $\mathrm{LB}, \mathrm{LB}+\mathrm{Ni}, \mathrm{LB}+\mathrm{Co}$, reaching the level of expression obtained in the wt strain grown in LB supplemented with either $\mathrm{Ni}$ or Co. This confirms that rcnA regulation by $\mathrm{Ni}$ or $\mathrm{Co}$ is mediated by $\mathrm{RenR}$ at the transcriptional level. In the wt strain, the addition of $\mathrm{Ni}$ or Co led to a similar level of induction (approximately fivefold) of $r c n R$. Interestingly, in an $r c n R$ mutant, $r c n R$ expression was the same for the three conditions ( $\mathrm{LB}, \mathrm{LB}+\mathrm{Ni}, \mathrm{LB}+\mathrm{Co}$ ), but the levels of expression were twofold higher than that of the wt strain grown in the presence of either $\mathrm{Ni}$ or Co. Thus, full expression of $r c n R$ is only attained in the absence of
A

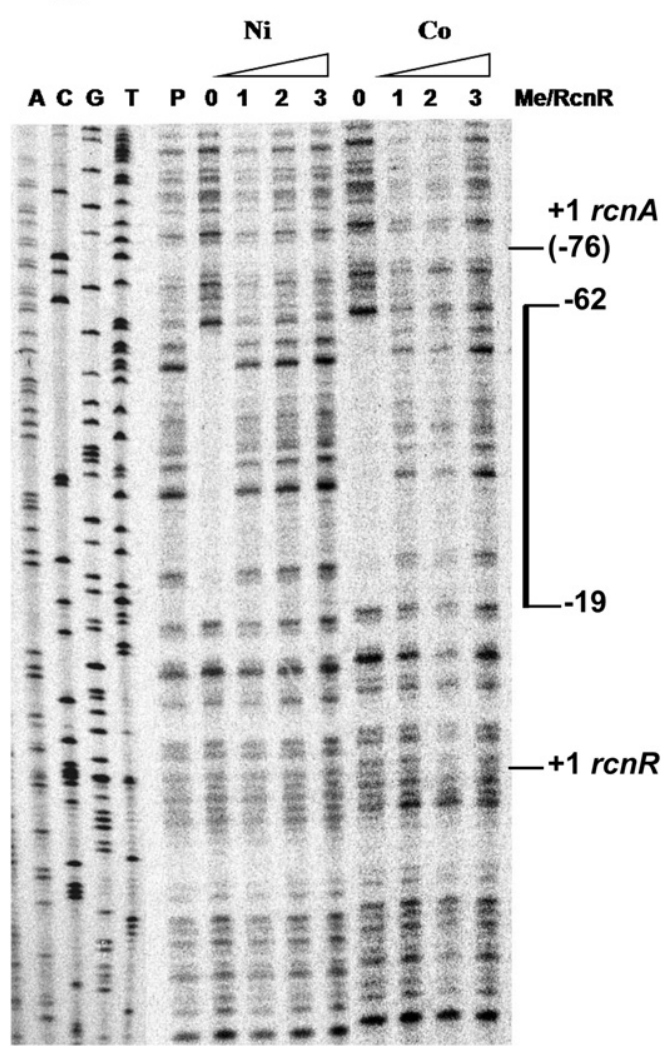

B

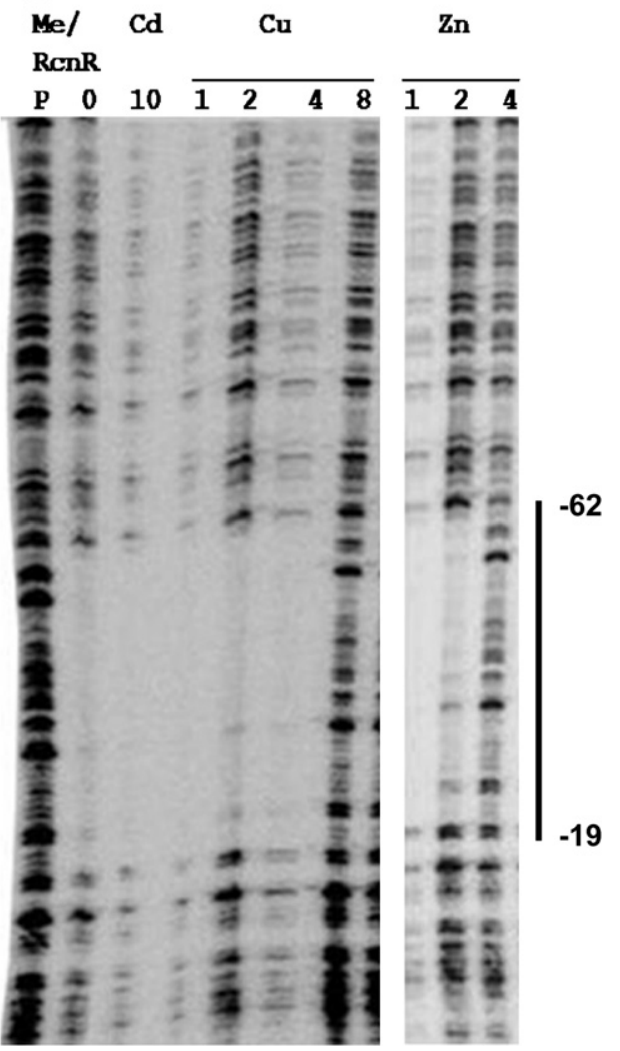

Fig. 2. RcnR dissociation from cognate DNA upon metal binding. A) Footprinting experiments in the presence of Ni or Co. Lane P: probe, lanes $0-3$ : probe +200 nM RcnR $+0,1,2$ or 3 equivalents of $\mathrm{Ni}$ or $\mathrm{Co}$. The region protected by $\mathrm{RcnR}(-62$ to -19$)$ is indicated relative to $r c n R$ transcription start site. B) RcnR metal specificity testing. Footprinting experiments in the presence of $\mathrm{Cd}, \mathrm{Cu}$ or $\mathrm{Zn}$. Lane P: probe, lanes $0,1,2,4,8,10$ : probe $+200 \mathrm{nM} \mathrm{RcnR}+0,1,2,4,8$ or 10 metal equivalents, with the corresponding metal indicated above. 
renA
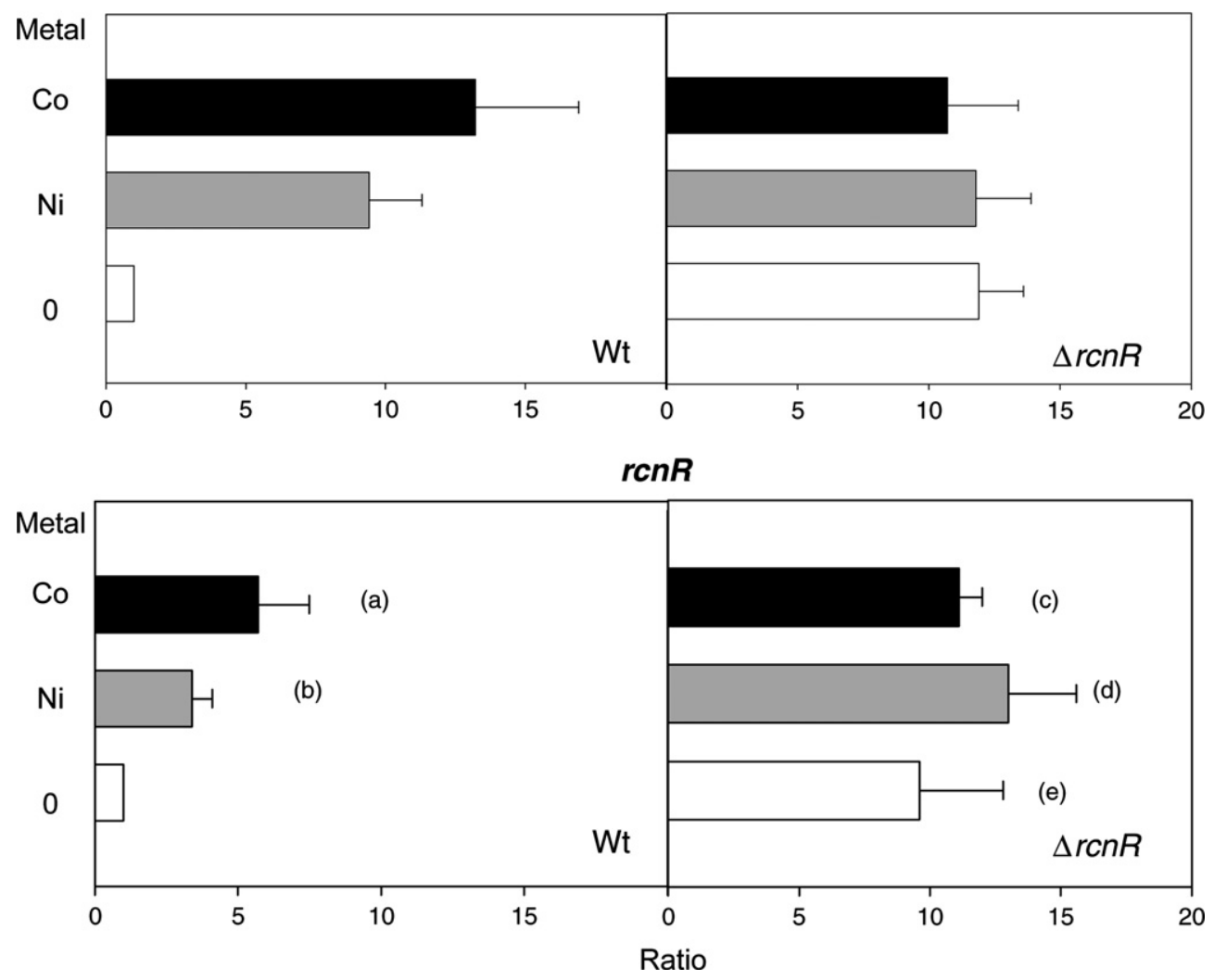

Fig. 3. Expression of $r c n R$ and $r c n A$ in response to $\mathrm{Ni}$ and Co. Quantification of the expression of the $r c n R$ and $r c n A$ genes was performed by qRT-PCR after growth of the wild-type strain NM522 and its $\Delta r c n R$ derivative until mid-log phase in $\mathrm{LB}$ (white bars), $\mathrm{LB}+1 \mathrm{mM} \mathrm{NiSO}_{4}$ (gray bars) or $\mathrm{LB}+0.1 \mathrm{mM} \mathrm{CoCl}$ (black bars). Expression ratios are relative to the data obtained with the wild-type cells grown in LB. Data are the mean of at least three independent datasets, SD are presented in the figure. There were significantly different values between groups (a, b) and (c, d, e), with $P$-values: $(\mathrm{a}, \mathrm{c})=1.4 \times 10^{-4}$; (b, d) $=4 \times 10^{-7} ;(\mathrm{b}, \mathrm{e})=0.01$.

RcnR and is not attained by the sole addition of $\mathrm{Ni}$ or $\mathrm{Co}$, as observed for rcnA. This shows that RenR controls its own expression and suggests that supplementary regulatory events may control the expression of $r c n R$ and therefore metal efflux.

\subsection{Regulation of the divergent operon is highly specific to $\mathrm{Ni}$ and $\mathrm{Co}$}

We have previously reported that in vivo regulation of the expression of the transcriptional $\operatorname{rcnA}:$ : uidA fusion is specifically induced by $\mathrm{Ni}$ or $\mathrm{Co}$ and that addition of $\mathrm{Cd}, \mathrm{Cu}$ or $\mathrm{Zn}$ did not have any effect on the transcription of $r c n A$ [5]. To test the in vitro specificity of the system, footprinting experiments were performed in the presence of $\mathrm{Cd}, \mathrm{Cu}$ or $\mathrm{Zn}$ (Fig. 2B). As expected the addition of up to 10 metal equivalents of $\mathrm{Cd}$ triggered no release of RcnR from the $r c n R-r c n A$ intergenic region. For $\mathrm{Cu}$ and $\mathrm{Zn}$, RcnR dissociated from the probe with the addition of 8 and 4 metal equivalents, respectively.

\section{Discussion}

We demonstrate in this work that $r c n A$ and $r c n R$ are coordinately expressed in E. coli via RcnR and we provide insight into the molecular mechanism of this process. We have previously shown that the in vivo induction of rcnA is dependent on $\mathrm{Ni}$ or Co ions [5]. Here, using in vitro footprint experiments, we present evidence that addition of one $\mathrm{Ni}$ or Co equivalent leads to the release of RcnR interaction from the two recognition sites lying in the $r c n R-r c n A$ promoter-operator region. Furthermore, the other transition metals $\mathrm{Cd}, \mathrm{Cu}$ and $\mathrm{Zn}$ were not able to regulate $r c n R-r c n A$ operator DNA binding or were active at far higher concentrations which may not be physiologically compatible. These results are in full agreement with the phenotypes associated with $r c n A$ mutants, namely resistance to $\mathrm{Ni}$ and $\mathrm{Co}$ and not to other divalent cations [5]. At both functional and regulatory levels, this system is dedicated to the detoxification of $\mathrm{Ni}$ and $\mathrm{Co}$. Until recently, E. coli RcnA was the only described member of this family of efflux pumps. However a new member, $\mathrm{MdrH}$, has recently been described in Pseudomonas putida which confers resistance to $\mathrm{Cd}, \mathrm{Zn}$ and $\mathrm{Ni}$; its expression is induced by $\mathrm{Cd}, \mathrm{Ni}, \mathrm{Zn}$ and $\mathrm{Co}[15]$. The $\mathrm{mdrH}$ gene is thought to be regulated by the upstream gene $m r e A$, which has the same expression pattern as the target gene. The RcnA family might therefore have broad substrate specificity and may have co-evolved as a metal transporter and a dedicated metallo-regulator.

We show here that the induction of $r c n R$ transcription occurs by direct binding of Ni or Co on RenR. Each monomer of RenR can accommodate either one $\mathrm{Ni}$ or one $\mathrm{Co}$ ion, as reported here and elsewhere [6]. However, in vivo Co concentrations tenfold lower than those of $\mathrm{Ni}$ induced comparable effects on transcription. It can be hypothesized that the cellular requirement for Co differs from that of Ni. Co is indeed much less used by biological systems than $\mathrm{Ni}$, especially in E. coli where Co utilization seems restricted to vitamin B12 import and use $[2,16]$. This was further supported by measuring the increase of the $\operatorname{rcn} A$ :: uidA gene fusion after growth in LB medium supplemented by $\mathrm{Ni}$ or Co. An increase in the $\beta$-glucuronidase activity was observed for $\mathrm{Ni}$ concentrations up 
to $1 \mathrm{mM}$, whereas the maximum was reached for $0.03 \mathrm{mM}$ Co. The toxic effect of these ions on the bacterial growth was recorded for Co and $\mathrm{Ni}$ concentrations greater than $0.1 \mathrm{mM}$ and $0.5 \mathrm{mM}$ respectively (data not shown). These data indicate that a similar amount of $\mathrm{Ni}$ or $\mathrm{Co}$ added to the growth medium results in different intracellular concentrations. Another clue is the respective harmfulness of the two metals. Although the effects of these two metals at the molecular level are not yet fully understood, one striking difference is the capacity for Co to compete with Fe in Fe-metallocenters, leading for instance to inactivation of iron-sulfur clusters [17]. The bacterial cell might therefore be inclined to control Co levels closely and export excess of the metal cation.

Transcription of rcnA was induced tenfold by $\mathrm{Ni}$ or $\mathrm{Co}$, as observed from qRT-PCR experiments. The same induction level was observed in the $r c n R$ mutant, indicating that saturating concentrations of $\mathrm{Ni}$ or Co fully alleviate repression via unbinding of $\mathrm{Ni}$ - or Co-loaded RcnR. The regulation of $r c n R$ seems more complex than regulation of $r c n A$. Indeed, induction levels with $\mathrm{Ni}$ or Co reached roughly fivefold. The difference in induction level of $r c n A$ and $r c n R$ might be due to different properties of each promoter, such as promoter strength. However, when measured in an rcnR background, the induction level of $r c n R$ increased tenfold, indicating that this regulation is mediated by RcnR. Thus, transcription of $r c n R$ includes an additional layer of regulation relative to the transcription of $r c n A$. Previous work has suggested that iron might induce $r c n R$, but in a fur-independent pathway [14]; this point needs further investigation.

The peculiar topology of the $r c n R$ and $r c n A$ promoters could also shed light on our understanding of these differential patterns of expression. We show here that the two promoters are convergent and that the two RcnR DNA binding boxes are symmetrically located from each transcription start site. This topology is not frequent and provides functional constraints on the transcription of the divergent genes. Convergent promoters in themselves were shown to trigger transcriptional interference of one gene over the divergent one, leading to increased expression of one of the genes and resulting in so-called "weak" and "strong" promoters. The competition between the "weak" and the "strong" promoters might be the result of two phenomena: (i) RNAP bound to one promoter decreases the interaction between RNAP and the second promoter and (ii) when both promoters are occupied by RNAP, transcription initiation occurs faster on one of the promoters $[18,19]$. We identified this kind of conserved promoter organization in $r \mathrm{rnA} / \mathrm{rcnR}$ systems of beta, gamma and delta Proteobacteria (data not shown). However the topology of the RcnR binding box is diverse as genes under its control may also be transcribed in the same orientation. Similarly tandem repeats of RcnR binding site is not an absolute rule, a single site being present in many cases (not shown). It has been shown experimentally that RcnR from $E$. coli can bind one site in vitro when the other one is missing [7]. The diversity in operator site organization may thus provide diversity in gene regulation among RcnR homologs which are involved in metal sensing and in oxidative stress response.

This work provides new insights on molecular mechanisms of transcriptional control of the efflux pump RcnA, but our genetics data suggest that additional yet unknown effectors modulate the regulation of $r c n R$. Further work is needed to identify these factors.

\section{Acknowledgements}

This work was supported by an Environmental Nuclear Toxicology grant from the Centre National de la Recherche Scientifique. We thank G. Effantin, S. Alvares and A. Campan for technical assistance, $\mathrm{V}$. James for correction of the English.

\section{Appendix. Supplementary information}

Supplementary data associated with this article can be found in the online version at doi:10.1016/j.biochi.2010.10.016.

\section{References}

[1] Y. Li, D.B. Zamble, Nickel homeostasis and nickel regulation: an overview, Chem. Rev. 109 (2009) 4617-4643.

[2] M. Kobayashi, S. Shimizu, Cobalt proteins, Eur. J. Biochem. 261 (1999) 1-9.

[3] Z. Ma, F.E Jacobsen, D.P. Giedroc, Coordination chemistry of bacterial metal transport and sensing, Chem. Rev. 109 (2009) 4644-4681.

[4] P. Gikas, Single and combined effects of nickel (Ni(II)) and cobalt $(\mathrm{Co}(\mathrm{II}))$ ions on activated sludge and on other aerobic microorganisms: a review, J. Hazard. Mater. 159 (2008) 187-203.

[5] A. Rodrigue, G. Effantin, M.A. Mandrand-Berthelot, Identification of rcnA (yohM), a nickel and cobalt resistance gene in Escherichia coli, J. Bacteriol. 187 (2005) 2912-2916.

[6] J.S. Iwig, S. Leitch, R.W. Herbst, M.J. Maroney, P.T. Chivers, Ni(II) and $\mathrm{Co}(\mathrm{II})$ sensing by Escherichia coli RcnR, J. Am. Chem. Soc. 130 (2008) 7592-7606.

[7] J.S. Iwig, P.T. Chivers, DNA recognition and wrapping by Escherichia coli RcnR, J. Mol. Biol. 393 (2009) 514-526.

[8] T. Liu, A. Ramesh, Z. Ma, S.K. Ward, L. Zhang, G.N. George, A.M. Talaat, J.C. Sacchettini, D.P. Giedroc, CsoR is a novel Mycobacterium tuberculosis copper-sensing transcriptional regulator, Nat. Chem. Biol. 3 (2007) 60-68.

[9] Z. Ma, D.M. Cowart, R.A. Scott, D.P. Giedroc, Molecular insights into the metal selectivity of the copper(I)-sensing repressor CsoR from Bacillus subtilis, Biochemistry 48 (2009) 3325-3334.

[10] K.A. Datsenko, B.L. Wanner, One-step inactivation of chromosomal genes in Escherichia coli K-12 using PCR products, Proc. Natl. Acad. Sci. U.S.A. 97 (2000) 6640-6645.

[11] D.J. Galas, A. Schmitz, DNAse footprinting: a simple method for the detection of protein-DNA binding specificity, Nucleic Acids Res. 5 (1978) 3157-3170.

[12] M.W. Pfaffl, A new mathematical model for relative quantification in real-time RT-PCR, Nucleic Acids Res. 29 (2001) e45.

[13] J.S. Iwig, J.L. Rowe, P.T. Chivers, Nickel homeostasis in Escherichia coli - the rcnR-rcnA efflux pathway and its linkage to NikR function, Mol. Microbiol. 62 (2006) 252-262.

[14] D. Koch, D.H. Nies, G. Grass, The RcnRA (YohLM) system of Escherichia coli: a connection between nickel, cobalt and iron homeostasis, Biometals 20 (2007) 759-771.

[15] A. Haritha, K.P. Sagar, A. Tiwari, P. Kiranmayi, A. Rodrigue, P.M. Mohan, S.S. Singh, MrdH, a novel metal resistance determinant of Pseudomonas putida KT2440, is flanked by metal-inducible mobile genetic elements, J. Bacteriol. 191 (2009) 5976-5987.

[16] S.B. Mulrooney, R.P. Hausinger, Nickel uptake and utilization by microorganisms, FEMS Microbiol. Rev. 27 (2003) 239-261.

[17] C. Ranquet, S. Ollagnier-de-Choudens, L. Loiseau, F. Barras, M. Fontecave, Cobalt stress in Escherichia coli. The effect on the iron-sulfur proteins, J. Biol. Chem. 282 (2007) 30442-30451.

[18] B.P. Callen, K.E. Shearwin, J.B. Egan, Transcriptional interference between convergent promoters caused by elongation over the promoter, Mol. Cell 14 (2004) 647-656.

[19] A. Protsenko, M. Zakharova, M. Nagornykh, A. Solonin, K. Severinov, Transcription regulation of restriction-modification system Ecl18kI, Nucleic Acids Res. 37 (2009) 5322-5330.

[20] F.W. Studier, A.H. Rosenberg, J.J. Dunn, J.W. Dubendorff, Use of T7 RNA polymerase to direct expression of cloned genes, Methods Enzymol. 185 (1990) 60-89.

[21] C. Perrin, R. Briandet, G. Jubelin, P. Lejeune, M.A. Mandrand-Berthelot, A. Rodrigue, C. Dorel, Nickel promotes biofilm formation by Escherichia coli K12 strains that produce curli, Appl. Environ. Microbiol. 75 (2009) 1723-1733. 